\author{
JIŘI SUBRT
}

\title{
SYSTÉMOVÁ DIFERENCIACE - RIZIKOVÝ POTENCIÁL SOUDOBÉ SPOLEČNOSTI
}

Tematika, na niž je orientován tento příspěvek, vychází z idejí systémové teorie, jež byly zformulovány čelním představitelem moderní německé sociologie Niklasem Luhmannem (1927-1998). Počátky Luhmannovy vědecké dráhy byly poznamenány vlivem amerického sociologa Talcotta Parsonse. Tento vliv však byl záhy překryt jinými podněty, které přicházely velmi často $\mathrm{z}$ oblasti mimo sociální vědy. Luhmann nalézá inspiraci $v$ takových oborech, jako je termodynamika, kybernetika, informační teorie, biologie či neurofyziologie. Byl ovlivněn operativní logikou Georga Spencera-Browna a biologickou teorii poznání chilského neurofyziologa Humberta R. Maturany. Přes všechny uvedené vlivy není Luhmannovo dílo v žádném případě eklektické, nýbrž značně originální a koncepčně jednotné.

\section{SYSTÉMOVA DIFERENCIACE A SEBEREFERENCNI UZAVR̆ENOST}

Luhmann je stoupencem evoluční teorie, kterou aplikoval na výklad strukturálních změn společností prítomných i minulých. Nárůsty komplexity a funkcionální diferenciace společnosti jsou pro něj podstatnými znaky společenského vývoje, který vede od archaických společností až ke společnostem moderním. Na tomto základě Luhmann konstruuje typologii tř́ evolučních typů strukturní diferenciace společenských systémů, které představuje společnost archaická $s$ diferenciací segmentační, dále společnost diferencovaná stratifikačně (hierarchicky) a konečně společnost moderní, diferencovaná funkcionálně.

Luhmann přejal ideu evolučního vývoje od Parsonse, avšak zatímco jeho předchủdce nazíral evoluční procesy změn $z$ hlediska vývoje integračních mechanismů, on sám zkoumá tento problém především optikou autonomizace dílčích společenských systémů. Do centra pozornosti tedy nestaví jako Parsons integraci, nýbrž diferenciaci; klíčovou pro něj není otázka podmínek zachování struktury, nýbrž proces sociokulturního rozrůzňování, resp. diferenciace (Ausdifferenzierung) společenského systému [Kiss 1986: 35].

V návaznosti na myšlenku sociální diferenciace, kterou formuloval již Herbert Spencer, považuje Luhmann za klíčový pro moderní společnost proces systémové funkcionální diferenciace. Moderní společnost je pro Luhmanna společnosti funkcio- 
nálně diferencovanou; je tvořena $\mathrm{z}$ nestejnorodých, avšak rovnocenných částí, které mají relativně samostatný charakter a které jsou označovány jako dílčí společenské systémy (Teilsysteme; subsystémy, systémy v systémech). Luhmann nikde ve svém díle nepodává žádný ucelený výčet těchto dílčích systémů, ačkoli je zřejmé, že jejich počet přesahuje minimálně jednu desítku. Patří $\mathrm{k}$ nim zejména ekonomika, politika, právo, armáda, věda, umění, náboženství, masmédia, výchova, zdravotnictví, sport, rodina a intimní vztahy.

Podstatné je především to, že každému $\mathrm{z}$ těchto systémů přisluší pouze jemu vlastní funkcionální specializace na určitou specifickou oblast dějủ, které se v něm odehrávají (ekonomické jednání je něco jiného než náboženství nebo intimní vztahy apod.; každému $\mathrm{z}$ těchto typů jednání je přisuzován jiný smysl a jím sledován jiný cíl). Každý $\mathrm{z}$ těchto dílčích systémů přispívá vzhledem ke své funkcionální specializaci jiným způsobem $\mathrm{k}$ reprodukci společnosti. Přes svoji nestejnorodost jsou subsystémy rovnocenné $v$ tom ohledu, že jsou pro tuto reprodukci všechny nezbytné, a lze říci, že i nezastupitelné, má-li si společnost udržet svůj charakter.

Vzájemná jednota těchto subsystémů je formována vztahy založenými na kombinaci jejich funkcionální uzavřenosti a zároveň otevřenosti vůči prostředí. Znamená to, že moderní společnost představuje diferencovanou jednotu, $\mathrm{tj}$. celek skládající se $\mathrm{z}$ funkcionálně závislých (tj. na funkce jiných systémů odkázaných) a zároveň autonomních dílčích systémů. Autonomie a závislost jsou zde ve vzájemně potencovaném, stupňovaném poměru (dílčí systémy se sice osamostatnily, ale zhroucení jednoho z nich mủže mít fatální důsledky pro společenský systém jako celek).

Luhmannova teorie si klade za cíl popsat svět za pomoci rozlišení pojmů systém a okolí (prostředí - Umwelt). Znamená to, že svět je v této perspektivě chápán jako souhrn toho, co tvoří systém a co se jako okolí nalézá vně systému. Systémy existují ve světě, bez něhož by nemohly existovat. Všechny jejich operace předpokládají v každém okamžiku strukturální vazbu k tomuto světu. Luhmann [1997: 92] tuto vazbu označuje výrazem (strukturelle) Kopplung a zkoumá ji jako otázku vztahủ systému k okolí a $\mathrm{k}$ jiným systémům. Základním problémem, který musí řešit každý systém, je, jak zajistit vlastní existenci propojením mezi vlastními elementy a mezi těmito elementy a okolím. Vymezování se vủči okolí, tzn. uchovávání hranic systému, je založeno na jednání, které reprodukuje vlastní systémovou identitu.

Okolí se systému může představovat různým způsobem, nikdy však samo o sobě nepředstavuje nějaký jednotný, ucelený systém. $\mathrm{K}$ okolí mohou patřit jiné, další systémy (např. biologické organismy nebo stroje), ale také ještě nediferencované, netematizované, potenciální oblasti a možné světy pro další vývoj. Luhmann [2002: 177] $\mathrm{v}$ dané souvislosti poukazuje na nutnost „odlišovat vztahy systému $\mathrm{k}$ jeho okolí od vztahů systému $\mathrm{k}$ jednotlivým systémům $\mathrm{v}$ jeho okolí“ (zatímco okolí je pro systém „abstraktní Jiné“, jiné systémy jsou pro něj „to Jiné“). Vztahy mezi systémem a jinými, okolními systémy přitom mohou nabývat rủznou kvalitu; mủže jít o tzv. „rezonanci“" (to je případ relací mezi dílčími společenskými systémy v moderní společnosti), anebo se mohou systémy „vzájemně umožňovat“ tak, že dochází k „penetraci“ nebo „interpenetraci“ (to, co se odehrává v relacích mezi psychickými a sociálními systémy nebo mezi psychickými systémy navzájem). 
Společenské systémy jsou sebereferenční, což znamená, že se při konstituci svých elementủ, operací a struktur vztahuji na sebe samé. Předpokladem této „sebevztaženosti“ “je schopnost systému sama sebe pozorovat a popisovat, podávat sebevýpověd. Na rozdíl od Parsonsovy koncepce systémủ, které jsou otevřeny (ve formě Input/Output) svému okolí, Luhmann [1984: 25, 1997: 92] zdůrazn̆uje sebereferenci sociálních systémů, jejich sebereferenční a operační uzavřenost (selbstreferentielle Geschlossenheit, operative Geschlossenheit); přesouvá těžiště svých úvah od otevřených k operačně uzavřeným systémům. U těchto systémů je nutné vycházet $\mathrm{z}$ jejich neredukovatelné autonomie a schopnosti stanovit si své vlastní mechanismy stabilizace, fungování a vývoje. Jsou to systémy založené na „sebevztaženosti“, které samy sebe organizují.

O sebereferenční uzavřenosti však nelze uvažovat $\mathbf{v}$ podobě, jakou představuje solipsismus či autismus. I když jsou systémy ve své výstavbě a reprodukci systémy uzavřenými, neznamená to, že nemohou vytvářet a nevytvářejí kontakt s okolím; naopak, bez těchto kontaktů by dynamika operačně uzavřených systémů zanikla. Např. univerzita jako systém může existovat pouze na pozadí fungujícího hospodářství, politického a právního systému atd. Okolní svět tedy rozhodně nepředstavuje nějakou bezvýznamnou zbytkovou kategorii, nýbrž naopak: pro systémy je poměr ke svému okolí konstitutivní a ony mohou trvat ve své existenci pouze $\mathrm{v}$ diferenci $\mathrm{k}$ němu.

\section{POLYKONTEXTUÁLNI REALITA, MULTICENTRICKÝ SVĚT}

Podmínkou existence sociálních systémů je komunikace. Aby nebyl „autopoietickỹ “ řetězec komunikace přerušen, vytvářeji si tyto systémy mechanismy, jejichž účelem je stabilizovat komunikační procesy. Tyto mechanismy označuje Luhmann jako média. Luhmannův pojem symbolicky generalizovaných komunikačních médií nelze zužovat na běžně chápané prostředky hromadné komunikace, nebot se týká takových médií, jako jsou moc, peníze, zákony, víra či vědění. Za jeden $\mathrm{z}$ hlavních znaků společenské evoluce považuje Luhmann diferenciaci jednotlivých komunikačních oblastí, jakými jsou politika, hospodářství, právo, náboženství, věda, ale také výchova, umění či intimní vztahy, spolu s odpovídajícími komunikačními médii.

Komunikace zprostředkovaná těmito médii $\mathrm{v}$ rámci jednotlivých subsystémů probíhá vždy $\mathrm{v}$ rámci určitého binárního kódu (např. $\mathrm{v}$ politickém systému: mít moc - nemít moc, $v$ ekonomickém systému: placení - neplacení, v právním systému: právo - bezpráví, ve vědě: pravda - nepravda, v náboženství: imanence - transcedence). Smysl, který je v rámci systému komunikován, je takto ohraničen dvěma póly binárního kódu, jež pro něj tímto způsobem vytvářejí hranice a stanovují jeho horizont, tzn. již předem určují aktérům, oč se jedná (boxer ví, že jeho úkolem je porazit protivníka a nikoli $s$ ním podepsat kontrakt o dodávce).

Díky těmto binárním kódủm, které vždy vyjadřují určitý typ jedné vůdčí diference, se vytvářejí subsystémově specifické sémantiky, $v$ nichž je autonomie jednotlivých subsystémů založena na aplikaci vlastní systémové vúdčí diference. Např. diferenciace ekonomiky jako autonomního společenského subsystému začíná etablováním symbolicky generalizovaného komunikačního média - vývojem peněz [Luhmann 1988: 
230]. Elementy ekonomiky (unit acts) jsou platby, binárním kódem placení/neplacení, jazyk představují ceny, které podmiňují a programují platby.

Kódy, které rozlišují mezi alternativami (kupř. norma/odchylka, úspěch/neúspěch, uznání/opovržení, krása/ošklivost, dobro/zlo), samy o sobě kritéria tohoto rozlišení neobsahují. Kritéria garantující správnost přiřazení hodnot kódu označuje Luhmann jako programy (Programme) [Baraldi 1997: 139]. Např. pro kód pravdivý - nepravdivý se ve vědeckém systému uplatňují taková kritéria, jako je platnost, spolehlivost, reprezentativnost, logická absence rozporu apod. Uvedená kritéria představují program, jehož specifická sémantická náplň umožňuje selekci podle přislušného binárního kódu. Na rozdíl od univerzality kódu bývá sémantika programu (a tedy i povaha kritérií) historicky relativní a proměnlivá.

Celkově je tedy logika fungování jednotlivých systémů taková, že má charakter zúženého, jednostranného pohledu, založeného na vysoce specializovaném binárním kódu, jímž jsou operace v př́slušném systému řízeny. A tak v ekonomice o všem nakonec rozhodují platby a ve sportu vítězství a nic podstatného na tomto jednoduchém faktu nemůže změnit ani komercionalizace sportu, díky níž se sportovní vítězství může stát dủvodem zvýšeného nakupování určitého zboží, anebo sponzorství a peněžní dary, které mohou výrazně ovlivnit pravděpodobnost vítězství určitého týmu. Jinak řečeno: v ekonomickém prostředí rozhoduje o pozici firmy nikoli počet sportovních vítězství, ale její peněžni zisky, ve sportu naopak rozhoduji o umístěni právě tato vítězství. Oba systémy tedy odděluje komunikativně nepřekročitelná hranice, kvůli které si tyto systémy nikdy nemohou navzájem úplně rozumět; jejich schopnost porozumění je apriorně zredukovaná podle přislušného binárního kódu a neumožňuje zcela adekvátně vyhodnotit evaluační orientace druhého systému.

Použitý příklad ukazuje, že existuje sebereferenční uzavřenost jednotlivých společenských subsystémů, ale i to, že existují určité cizí referenční vlivy, které do těchto subsystémů zasahují, nebot ty - přes svoji sebereferenční uzavřenost - jsou přece jen otevřené vůči svému prostředí. Aby taková vnější „iritace“ mohla působit větší měrou, musí zapůsobit na programovou strukturu daného subsystému. Ve sportu takovou strukturu představují soutěžní pravidla, v ekonomice jsou to finanční kalkulace, ve vědě teorie a metodologie. Uvedené programy sebereferenčně ustanovují pravidla, která umožňují porozumět používaným kódủm, a jsou také v té či oné míre otevřeny vlivům, které přicházejí zvnějšku. Vědecký výzkum je například ovlivňován politickými rozhodnutími, právními regulativy nebo finančními dotacemi. $V_{\text {i }}$ tomto směru lze konstatovat, že cizí prvky a vlivy mohou pủsobit na systém restriktivně, nebo naopak orientačně či podpủrně, mohou tedy jeho sebereferenci rủznou měrou kanalizovat, avšak nikdy nemohou jeho základní kód zrušit, zbavit ho platnosti.

Celá situace je pak navíc komplikována i tím, že jednotlivé události, které se ve společnosti odehrávají, jsou většinou polykontextuální, tedy že vytvářejí více rủzných rámců relevance či smysluplných významủ v závislosti na množství hledisek či perspektivy, $\mathrm{z}$ nichž jsou nazírány (anebo jinak řečeno: $\mathrm{v}$ rámci jednotlivých událostí lze jen stěží předpokládat existenci nějakých jednoznačně vymezených kompetenčních okruhů, jichž by se komunikace probíhající v rámci jiných systémů vủbec nedotýkala). Tak např. havárie způsobená živelnou pohromou je událostí, která se nějakým zpư- 
sobem týká systému ekonomického, politického, právního, vojenského, zdravotního, masmediálního, vědecko-technického či uměleckého ad., přitom ale pokaždé jinak. Znamená to, že společenská skutečnost existuje mnohonásobně $\mathrm{v}$ mnoha rủzných podobách $\mathrm{v}$ závislosti na specifických systémových perspektivách; vyjádřeno jinými slovy: funkcionální diferenciace produkuje multiplicitu realit. Určitá společenská událost se jeví jinak $\mathrm{z}$ ekonomického pohledu a jinak $\mathrm{z}$ hlediska politiky nebo náboženství. Jednota společnosti přitom podle Luhmanna [1986: 216] není paradoxně ničím jiným než právě touto mnohostí, touto funkcionální diferenciací společenských systémủ.

Problém, jak jsme již ukázali, spočívá $v$ tom, že každý dílčí systém si na základě vlastního pozorování vytváríi o společnosti svůj vlastní obraz (to, co pozoruje napřiklad právní systém, není nic jiného než společnost, avšak pozorovaná skrze aplikaci rozlišení právo - bezpráví). $V$ dủsledku přijaté binární schematizace pak mohou jednotlivé systémy vidět jenom to, co jim tato schematizace dovoluje, a nevidí to, co vidět nemohou. Jednotný obraz společnosti se rozpadá do těchto dílčích pozorování a na místo centricky pojímaného světa nastupuje svět multicentrický [Luhmann 1984: 284].

Luhmannovo multicentrické pojetí světa zde až překvapivým zpủsobem koresponduje s diagnózami postmoderních myslitelủ, jako je Jean-François Lyotard [1993] rozvijející Wittgensteinovu teorii jazykových her (Schprachspiele). Podle ní se komunikace uskutečňuje $v$ rámci rủzných druhủ diskurzủ (náboženství, umění, věda...), jež jsou heterogenní a navzájem nepřeložitelné. Neexistují ani žádná univerzální pravidla pro to, který druh diskurzu by měl mít přednost. Jde o situaci radikální plurality, kterou nelze pochopit a vyložit na základě jednoho modelu.

Afinitu mezi Luhmannovou teorií a postmodernismem ostatně potvrzuje i Zygmunt Bauman [1995: 20], jenž poukazuje na nutnost ,podrobit základní revizi pojem systému neboli způsobu, jímž jsou rủznorodé elementy lidského společenství, rozmanité prvky činností a životního procesu či rủzné regulativní pojmy, koncepce a představy do sebe navzájem zaklíněny a jímž vstupuji do interakce a kooperativního vztahu“. Bauman považuje za žádoucí „uznat, že 'systémovost' nespočívá ve vzájemném vyvažování a přizpủsobování elementủ systému, ve tvorbě vzorcủ takového vyrovnávání a v efektivním vylučování všech odchylek od těchto vzorcủ, ale že se spíše tvoří jako kaleidoskopický obraz ze hry rozporủ, napětí a ambivalencí, dohadování a sporů, porozumění a nedorozumění. A že neurčitost a mnohoznačnost komunikujících elementủ není projevem nemoci systému, ale podmínkou jeho životnosti““.

Podle Luhmannova názoru dospěla dnes sociokulturní evoluce do takového stadia, v němž lze hovořit o zeměkouli obepínající „světové společnosti“" (Weltgesellschaft). Svět dnes tvoři globální „,světový systém“, který se týká všech společností a který je charakterizován postupným mizením teritoriálních hranic a komunikačních limitủ. V dủsledku globalizace stěží najdeme na zeměkouli „bílá místa“, která by nebyla vtaŽena do celosvětového systému komunikací, interdependencí a kontingencí.

$\mathrm{V}$ rámci světové společnosti se $\mathrm{z}$ hlediska systémové teorie nyní rýsuji nové hranice, nejsou to hranice státní (i když ty stále existují), nýbrž hranice vytvářené jednotlivými funkcionálně diferencovanými subsystémy, $\mathrm{v}$ nichž se setkáváme $\mathrm{s}$ komunikacemi majícími celosvětový rozsah (např. mezinárodní politika, ekonomika, věda, právo, náboženství, sport). Př́íciny toho, že za této situace jsou zároveň reprodukovány i hra- 
nice teritoriální, spatřuje Luhmann právě ve fungování uvedených systémủ: jsou to politické důvody, kvưli nimž se upevňuje regionální segmentace politického systému světové společnosti do států, a jsou to hospodářské dủvody, které podporují diferenciaci na centrum a periferii, na vysoce rozvinuté a rozvojové regiony [Luhmann 1986: 168].

\section{ESKALACE NAROKU்}

V Luhmannově systémové teorii jsou individua zachycena jako psychické, event. personální systémy (psychische/personale Systeme). Jedna z významných premis této teorie říká, že psychické systémy představují pro sociální systém ${ }^{1}$ „pouze“ jeho okolí. To je důvod, proč někteři kritikové Luhmannovi vytýkají, že jeho teorie je nehumánní a že projektuje společnost bez lidí. Jedná se však o metodologický antihumanismus, nikoliv o normativ. Tento metodologický antihumanismus vychází z premisy, že jednotlivé osoby př́sluši $\mathrm{k}$ sociálnímu systému pouze určitým typem jednání (podle T. Parsonse k němu př́sluší svou ,rolí“). Konkrétní lidé, jejich organické a psychické vlastnosti nejsou součástí sociálního systému, nýbrž jeho okolím. Tím nicméně není a nemá být řečeno, že lidé jsou pro sociální systém nedůležití.

Vyjádřeno formulací I. Šrubaře [2002: 270], je životní dủležitost psychických systémủ pro sociální systémy dána tím, že „sociální systémy vznikaji z šumủ, jimiž se psychické systémy pokoušejí komunikovat. Proces komunikace jako organizace sociálního systému sestává“, jak konstatuje tento autor, „ve své nejjednodučší formě ze žretězení těchto šumủ do jistého vzorce, $v$ němž z pozorovatelné následnosti subjektivních aktů vznikají nadsubjektivní očekávání, orientující další prủběh komunikace“.

Psychické a sociální systémy se ve své výstavbě navzájem ovlivňují. Pro vztahy mezi člověkem a sociálním systémem používá Luhmann pojmy koevoluce (označující jejich společný, vzájemně se podmiňující vývoj) a interpenetrace. Interpenetrace je umožněna tím, že sociálni a psychické systémy jsou si „podobné“, nebot operují na základě smyslu (smysl používají jako svủj operační modus); tím se liši od jiných systémů, např. od strojủ. Proces interpenetrace předpokládá, že dva odlišné systémy mohou jeden druhý umožňovat tak, že si vzájemně dají k dispozici svoji komplexitu [Luhmann 1984: 290]; samy při tom nesplývají, ale zủstávají jeden pro druhého okolím. Samozřejmě je tu i podstatný rozdíl: oba typy systémủ (psychický a sociální) jsou organizovány odlišným způsobem: psychické se organizují na základě vědomí, sociální na základě komunikace.

Někteří myslitelé zabývající se problémy postavení individua $v$ soudobé společnosti staví do poprééi otázku absurdity lidské existence a absence smyslu lidského života, kterými jsou zde jedinci postiženi. Tento jev bývá namnoze interpretován jako dủsledek weberovského „odkouzleni““ ve smyslu eroze religiozity a prosazujících se sekularizačních tendencí. Luhmann [1984: 362], jak je pro něj typické, však tyto zavedené představy problematizuje - $\mathrm{v}$ daném případě poukazem na to, že se zde nejedná o nic jiného než o dobově podmíněný typ sebepopisování psychických systémů.

1 Luhmann rozlišuje tři úrovně sociálních systémú: interaǩní, organizační a společenské. Tato studie je věnována systémúm společenským. 
Každý popis podle tohoto teoretika předpokládá nějakou základní diferenciaci. O historickém vývoji moderny lze říci, že jsou $v$ něm jedinci zbavováni vztahu $\mathrm{k}$ religiózní dimenzi svého života, která jim takovou diferenciaci zajištovala. Lidské ,jā“ (pro něž je tato diferenciace předpokladem vlastní fixace) naráží na sebe sama a hledá svůj externí protějšek v něčem jiném. Obrací se ke společnosti. Tím se ale vytváři nové problémy, nebot tato orientace získává podobu diferenciace mezi tím, co je (co společnost jedinci poskytuje), a tím, co by být mělo (co by mu měla poskytovat). Jedinec tímto způsobem identifikuje sebe sama prostřednictvím svých nárokủ. Moderní individualismus je podle Luhmanna $\mathrm{z}$ podstatné části individualismem těchto nároků. Ty tak vyvolávají nebezpečí, které lze označit jako ,inflaci nárokủ“ [Schimank 2000: 132-135]. Dủvodem zmíněné inflace je podle Luhmanna [1995: 140] fungování binárních kódủ jednotlivých společenských subsystémů, kterým chybí to, co bychom mohli chápat jako „racionální kritérium správné míry“ nebo jako „stop“ pravidlo nařizující ukončení.

$\mathrm{V}$ důsledku toho dochází $\mathrm{k}$ situaci, kdy funkcionálně diferencovaná společnost nejenže u svých členů určité nároky indikuje, ale sama také přispívá $k$ jejich ustavičné eskalaci a předbíhání. Týká se to především šancí podílet se na konzumu (v ekonomickém systému), na péči státu o blaho lidu (politického systému), lékařské péči (zdravotního systému), vzdělání (výchovného systému), sportu (sportovního systému), na informacích a zábavě (masmédii). Roztáčení inflační spirály nárokủ navíc posiluje představa - podle Luhmanna značně nerealistická -, že všestranný růst umožní více blahobytu a lepší, spravedlivější rozdělování. Autor ukazuje, že tato představa se v realitě střetává $\mathrm{s}$ řadou problémů. Patří $\mathrm{k}$ ním skutečnost, že některé statky nelze rozmnožovat libovolně, nebot pak ztrácejí svou hodnotu (např. vysokoškolské vzdělání); ale také to, že některé možné výkony narážejí na určité rủstové hranice, jež jsou dány enormní výší nákladů (např. ve zdravotnictví); zatímco jinde jsou takové hranice ze strachu před následky rozšířené nespokojenosti ignorovány (aby nebyl ohrožen standard spolřeby, přehlížejí se problémy životního prostředí).

Otázka nárokủ je ovšem navíc komplikována i faktem existující sociální nerovnosti, různými možnostmi participace na vyprodukovaném společenském bohatství, procesy inkluze a exkluze. Tak dochází $k$ tomu, že funkcionálně diferencovaná společnost mủže vyvolávat nejen inflaci nárokủ, ale může též přispívat ke š̌etězení efektủ exkluze, kdy jsou tyto efekty jakoby umocňovány nebo násobeny počtem systémů, ve kterých $\mathrm{k}$ nim dochází (příjmy, vzdělání, právni ochrana, lékařská péče atd.) [Schimank 2000: 135-136].

Formulací tohoto soudu ovšem Luhmann zároveň připouští, že funkční diferenciace vydělující jednotlivé dílčí společenské systémy není jediným diferenciačním principem soudobých společností. Vedle něj se na jiné úrovni prosazuje další dủležitá diferenciační osa, která má jistý přesahující (metadiferenciační) charakter, a to diference na základě opozice „inkludovaný - exkludovaný“, vztahující se na lidské jedince (resp. psychické / personální systémy). Dủležité je nicméně i to, že v současnosti je tato diferenciace výraznější v méně rozvinutých oblastech světového systému, tedy tam, kde je zároveň na nižší úrovni diferenciace systémová.

Dodejme ještě, že soudobá sociologie věnuje pozornost nejen individuálním, ale i kolektivnim aktérủm. Jedním $\mathrm{z}$ těchto kolektivních aktérủ, s nimiž jsou dnes spojovány 
naděje těch, kteří touži po nápravě společenských nedostatkủ, jsou nová sociální hnutí (ekologická, mírová, ženská, občanské iniciativy atd.). Luhmann se sice tomuto tématu nikdy systematicky nevěnoval, dotkl se ho však v souvislosti s diskusemi o ekologii. Jeho hodnocení ekologických hnutí je značně ambivalentní. Rozhodně nepopírá, že tato hnutí právem upozorňují na existující problémy, které vyplývají z povahy soudobé funkcionálně diferencované společnosti. Pokud by taková hnutí neexistovala, nikdo by patrně - kromě expertů - o soudobých ekologických problémech nevěděl. Zároveň však Luhmann konstatuje, že novým sociálním hnutím chybí adekvátní koncepce popisu moderní funkcionálně diferencované společnosti (který - můžeme dodat - přináší právě systémová teorie). To, co je pro ně naopak charakteristické, je prostá fixace na určité postuláty a cíle, která je vázána na rozlišování príznivcủ a protivníkủ a spojena s odpovídajícím morálním hodnocením [Luhmann 1986: 234].

Jako předmět protestní komunikace se nejlépe hodí rozporuplná témata, z nichž zejména dvě nabyla díky svému povšechnému významu na intenzitě. Jedním z nich je otázka sociální rovnosti a nerovnosti, druhým otázka externí, společenské a ekologické rovnováhy. Sociální hnutí podle Luhmanna nedokážou v žádném z obou případủ dosáhnout více než vyvolat poboư̌ení či paniku, skandalizaci nebo šíření strachu (,komunikaci strachu“). A jestliže pak společným jmenovatelem těchto tendencí není ve své podstatě nic jiného než protest proti funkcionální diferenci společenského systému, nezbývá Luhmannovi, než aby tato hnutí odmítl, nebot $\mathrm{z}$ jeho pohledu tento systém žádné alternativy nemá - pokud ovšem nemá nastoupit regres a my se nemáme vrátit nazpět $k$ nějakému evolučně překonanému stupni společenského vývoje, nebot výdobytky moderny nelze uchovat, jestliže bychom se toho, co bylo funkcionální diferenciací dosaženo, vzdali [Luhmann 1994: 197]. Autor sice připouští, že v určitých dílčích záležitostech, jako např. v otázce energetických zdrojů, lze alternativy vymýšlet a předkládat $k$ výběru, avšak to podle jeho soudu není nic nového nebo zvláštního, nebot takto se autopoietické sociální systémy chovají samy od sebe.

\section{REZONANCE, MONITORING, FILTRACE}

Z perspektivy Luhmannovy systémové teorie lze prírodu nahližet jako fyzikální, chemické a biologické systémy a souvislosti, jejichž existence je předpokladem pro fungování společenského systému. To jak známo nijak nebrání tomu, aby společnost do př́rody nejen zasahovala, ale také ji i narušovala. To, co se dnes označuje jako ekologické problémy, je $\mathrm{z}$ hlediska systémové teorie zkoumáno jako problém vztahu společenského systému a jeho přirodního okolí. Pro uvedený vztah je charakteristické, že mnoho společenských subsystémů operuje $\mathrm{v}$ přirozeném životním prostředí $\mathrm{s}$ indiferencí vůči následkủm tohoto svého působení, což ve svém dủsledku vede $\mathrm{k}$ ohrožení reprodukční schopnosti moderní společnosti. Nejedná se zde přitom jen o nějaké náhodné nehody, nýbrž o zásadní problémy fungování systémových struktur.

Způsob, jakým jsou jednotlivé společenské subsystémy schopny vnímat ekologická ohrožení a rizika, spojuje Luhmann s výrazem „rezonance“. Dospívá k závěru, že problémem soudobé funkcionální diferenciace je přiliš nízká rezonance toho, co se odehrává v okolních systémech. Jestliže je v hospodářském systému zpracování informací 
vázáno na ceny, pak to znamená, že tímto jazykem je vše „filtrováno“; na poruchy, které v něm nelze vyjádřit, nemůže ekonomika reagovat. Toto omezení však nemusí být jen nevýhodou, nebot zaručuje, že bude-li problém $\mathrm{v}$ cenách vyjádřen, bude $\mathrm{v}$ systému zpracován [Luhmann 1986: 122an.]. Podobně jako ekonomika vnímají svůj okolní svět selektivně - prostréednictvím přislušných kódů a programů - $\mathrm{i}$ jiné dílčí systémy. $\mathrm{V}$ dủsledku toho mohou vznikat mezi jednotlivými subsystémy nejrůznější interakční efekty, jež mohou rezonanci tlumit, ale mohou ji také nepřiměřeně vystupňovat, a tím zpưsobovat nejrůznější společenské poruchy. Ve společenském systému tak múže být paradoxně vytvářeno rezonance nejen př́liš málo, ale i príliš mnoho.

Luhmann ukazuje, že rozhodně nelze považovat za samožrejmé to, že stavy a změny životního prostředí naleznou ve společnosti adekvátní rezonanci. Naopak, sociokulturní evoluce byla zjevně založena na faktu, že společnost jako relativně uzavřený systém na své prostředí př́liš nereagovala [Luhmann 1986: 42]. Změnit tuto situaci se přitom zdá být neřešitelné, nebot každé „zvýšené úsilí o kontrolu životního prostředí vede nutně $k$ další diferenciaci systémové komunikace, a tudíž snižuje možnost centrálního řešení ekologických problémů, které by zároveň znamenalo snížení samostatného fungování společenských subsystémů, a tudiž i snížení úrovně již evolučně dosaženého systémového vývoje“ [Šrubař 2002: 275].

Ohrožení nebo ničení přírody je, jak Luhmann zdůrazňuje, společensky relevantním jedině tehdy, je-li komunikováno, tedy stalo-li se předmětem nějaké komunikační události. Živočichové mohou umírat, lidé mohou trpět nemocemi, podmínky života se mohou zhoršovat, ale dokud se to nestane předmětem komunikace, nemá to „žádné společenské účinky“ [Luhmann 1986: 63]. Z povahy moderní společnosti zároveň vyplývá, že taková komunikace je vzhledem $\mathrm{k}$ množství médií a kódů stále problematičtějš́í.

Lze samozřejmě uvažovat o tom, že účinky negativních dopadủ na životní prostředí se mohou projevovat latentně, „za zády“ komunikačního procesu, a že v určitých připadech mohou dokonce nabýt apokalyptickou podobu ničivých ekologických katastrof. Luhmann nicméně trvá na tom, že společenské dopady ekologických problémů (externalit společenského operování) mohou být monitorovány a zpracovávány jen podle měřitek přislušných binárních kódů jednotlivých společenských subsystémů [Luhmann 1986: 218]. Ekonomika, jak jsme již naznačili, se stává vnimavou vůči svému prírodnímu prostředí pouze tehdy, jestliže ho dokáže zachytit v kódu orientovaném na finanční náklady a výnosy. Avšak to dlouhou dobu znamenalo a stále ještě často znamená, že $\mathrm{z}$ hlediska nákladủ je pro ekonomiku výhodnější se o dlouhodobější príirodni a společenské požadavky nestarat. Pokud jde o subsystém vědy, ten má schopnost odhalovat poznatky a technologie, které mohou životní prostředí ničit, ale i monitorovat a chránit, avšak sám nemá potenciál $\mathrm{k}$ jejich uplatnění. Vědecké poznatky se mohou prosadit jedině prostřednictvím aplikací $\mathrm{v}$ jiných systémových oblastech.

Apely na morálku a morální cítění, které bývají v diskusích o ekologických problémech často formulovány, považuje Luhmann za nic neřešíí podvádění sebe sama. Rozšîrený sklon vymáhat $\mathrm{v}$ této situaci morální odpovědnost je $\mathrm{z}$ jeho pohledu pouhým „gestem zoufalstvi““ [Luhmann 1986: 133], nebot vše nakonec obvykle končí u otázky, jaké nároky je schopen vnímat a zabezpečit ekonomický systém. 


\section{STRUKTURALNI VAZBY}

Navzdory sebereferenční komunikační uzavřenosti jednotlivých společenských subsystémů nelze říci, že tyto dílčí systémy operují pouze ve svém vlastním světě, nezávisle na sobě, nýbrž naopak platí, že mezi nimi existují nejrůznější strukturální vazby (Kopplungen). Zároveň však sebereferenční uzavřenost také znamená, že moderní polykontextuální společnost už nemůže pro systémovou analýzu představovat substanciálně uchopitelnou jednotu, že tedy $v$ jejím př́padě už nelze uvažovat o subsystémových funkcích z perspektivy celku (tak jak je tomu např. ještě u Parsonse).

Strukturální vazby mezi jednotlivými systémy jsou kontingentními produkty subsystémové koevoluce; příkladem provázanosti politiky a ekonomiky je financování politiky $\mathrm{z}$ daňových př́ijmů; vazbu ekonomiky na výzkum představuje například financování určitých výzkumných projektů. Na druhém $\mathrm{z}$ obou př́ikladủ lze rovněž dokumentovat, jak taková vzájemná evoluční adaptace dvou systémů mủže vypadat: Hospodářská oblast registruje, že investice založené na technologiích vycházejících z nejnovějších vědeckých poznatkủ se velmi dobře zhodnocují, a proto poskytuje vědě prostředky na takto cílené výzkumné programy. Takto se stává, že v oblasti vědeckého výzkumu jsou preferována určitá témata, která tímto způsobem dostávají zvláštní šanci pro komunikaci (kódovanou $\mathrm{v}$ této oblasti prostřednictvím binární opozice prav$\mathrm{da}$ - nepravda). Ve svém důsledku nakonec dochází $\mathrm{k}$ tomu, že ekonomické konjunkturální zájmy konjunkturálně ovlivňuji i volbu vědeckých témat a oba subsystémy vcházejí prostřednictvím modu financování vědy do trvalé synchronizace. Uvedený modus tedy zajištuje, aby se obě oblasti komunikace - jakkoli jsou sebereferenčně uzavřené - vzájemně zásobovaly iritacemi, jež směřují $k$ dlouhodobějšímu, nikoli jen epizodickému zohlednění zájmů příslušných sybsystémů [Schimank 2000: 130].

Vytváření takových strukturálních vazeb mezi jednotlivými subsystémy je však neustále provázeno tím, co lze označit jako indiferenci jednoho systému vủči sebereferenci druhého systému. Jestliže se tedy např. politika snaží pomocí určitých nástrojủ řídit jiné systémy, lze to $\mathrm{z}$ hlediska Luhmannovy systémové teorie chápat jako snahu o cílené ovlivňování s úmyslem posílit určité funkční projevy $\mathrm{v}$ jiných systémech. $Z$ hlediska komunikace uvnitř samotného politického systému však jde vždy o specifické komunikační souvislosti, které mají na zřeteli sobě vlastní politický kód, jenž je orientován na nárůst legitimní moci. Dủsledkem je mj. to, že politika přijímá svá rozhodnutí vždy ze zřetelem na očekávanou odezvu voličủ, přičemž nepopulární (byt by mohla být pro jiný systém velmi prospěšná) opatření se snaží v co možná největší míře eliminovat; tím jsou jeji možnosti limitovány. Obecně tedy platí, že účinky, které přináší operování jednoho systému, se mohou nějakým způsobem projevit i u jiných systémů.

Charakter soudobé společnosti je tedy podle Luhmanna vytvářen jednoduše tím, že vedle sebe existuje řada různých subsystémủ, mezi kterými vznikaji nejrůznější strukturální vazby; uvažovat však o nějaké (celo)systémové integraci (celo)společenského systému ve smyslu koordinace nebo řízení této spletité sítě z nějakého řídícího centra považuje tento autor za bezpředmětné a neopodstatněné.

Jako problém se $\mathrm{v}$ daném kontextu jeví zejména skutečnost, že operace jednoho systému mohou stavět jiné systémy před obtížně řešitelné, nebo dokonce neřešitelné 
problémy. Tak tomu je zejména tehdy, jestliže jeden subsystém nedokáže produkovat výkony - v určité kvantitě či kvalitě -, na nichž je závislý druhý subsystém (např. výchovný systém nedodává dostatek kvalifikovaných jedinců ekonomice či vědě). Druhým př́padem je situace, $v$ níž jeden systém vytváři externality, které mají negativní dopad na druhé (např. vojenský systém může odčerpávat finanční prostředky, které pak chybí ve školství, kulture nebo zdravotnictví). Oba typy problémů jsou ve své podstatě chronickými slabinami sebereference založené na binárním kódování a soudobá společnost mủže za úspěch považovat nanejvýš to, že žádný $z$ uvedených dvou připadů nezajde za únosnou mez. Mechanismus, který by zabránil tomu, že $\mathrm{k}$ něčemu takovému $v$ budoucnu nedojde, však podle Luhmanna neexistuje. A z faktu, že dosavadní vývoj probíhal celkem přiznivě, nelze žádné garance pro budoucnost vyvozovat.

\section{PROBLEMATICKÝ ŔÁD}

Luhmannova analýza ukazuje soudobou společnost jako celek rozdiferencovaný na funkcionálně závislé, zároveň však autonomní dílčí systémy, které jsou pro sebe navzájem okolními světy. Tím je logicky nastolena otázka existence či neexistence možných sjednocujících sil či integračních mechanismů.

Řada sociálních vědcủ předpokládá, že společnost je ovládána určitým dílčím společenským systémem. Pro některé $\mathrm{z}$ nich je tímto systémem ekonomika, pro jiné politika nebo náboženství. Luhmann takový způsob myšlení zavrhuje, nebot se domnívá, že je možné ho uplatňovat pouze na historicky předchozí, překonaný stratifikovaný typ společnosti (ve středověké společnosti je např. dominantní šlechta jako nositelka rozhodujíci - ozbrojené - moci), avšak nikoli na soudobou moderní společnost (podle autora je tomu vlastně naopak: největší tlaky v soudobé společnosti nevyvolávají silné subsystémy, nýbrž systémy slabé, problematicky fungující či „churavé“).

V historii systémového přistupu, sahající od Emila Durkheima k Talcottu Parsonsovi, převládalo jako dominantní hledisko dělby práce. Podle něj spolu rủzné oblasti společnosti navzájem kooperují na společném celku, podobně jako se tomu děje $v$ př́ipadě jednotlivých oddělení v rámci podniku. Dojde-li při tom v některé $\mathrm{z}$ kooperujících částí $k$ nějakému výkyvu nebo poruše, snaži se centrálni regulační mechanismy (at už vědomě, nebo spiše živelně) tento nedostatek odstranit a nastolit mezi jednotlivými částmi znovu vzájemnou proporcionální spolupráci.

Luhmann však vidí tento problém poněkud jinak. Dospívá $\mathrm{k}$ závěru, že každý dílčí systém má sklon $k$ sebeabsolutizaci spojené $s$ určitou „lhostejnosti“" $k$ tomu, co se odehrává v okolních systémech (např. ekonomický systém je orientován na ekonomické zretele bez ohledu na to, zda to, co je pro něj cenné, je či není př́nosné i po stránce umělecké, zdravotní nebo rodinné). Tato sebeabsolutizace by nepřinášela problémy jedině v prípadě, že by jednotlivé systémy fungovaly zcela nezávisle na sobě, protože tomu ale tak není, stává se zdrojem nejrůznějších napětí (politické mocenské zásahy mohou např. mařit určité ekonomické investiční záměry).

Logicky zde vyvstává otázka, jak je možný sociální rád za podmínek, kdy nelze spoléhat na žádnou společenskou „pospolitost“, žádný společný cíl jednání ani žádný intersystémový konsenzus. Němečtí sociologové Georg Kneer a Armin Nassehi [1993] 
interpretují Luhmannovo stanovisko jednoduše jako předpoklad, že řád vzniká spontánně tím, jak sociální systémy operují v hranicích, které si vytvořily. Jednotlivé operace jednotlivých systémů se zkrátka řadí vedle sebe, a tím dochází $\mathrm{k}$ samovolné výstavbě řadu, aniž by $\mathrm{k}$ tomu byly nutné nějaké společné perspektivy nebo dorozumění o společných cílech, normách či hodnotách. To, že se řád vytváři spontánně, však neznamená, že je bezproblémový. Funkcionální diferenciace neznamená, že jednotlivé části společnosti už spolu nemají vzájemně co dělat, ale spíše to, že se nacházejí v napjatém vztahu [Pongs 2000: 172].

Nassehi zdůrazňuje, že diferenciace $v$ Luhmannově pojetí neznamená dĕlení ve smyslu rozdělováni nějakého hotového celku na části, nýbrž proces, který probíhá evoluční cestou „odspodu“, přičemž současnou sestavu dílčích systémů nelze rozhodně chápat ani jako vyjádření nějaké transcendentální potřeby společenského systému, ani jako historickou nutnost. Proces tvorby systémủ je kontingentní a není určován žádným mechanismem působícím nad tímto procesem nebo v jeho pozadí. Pro lepší chápání těchto otázek proto autor navrhuje opustit zcela pojem „dílčí systém“ (Teilsystem), který přiliš sugeruje starou, překonanou představu o celku a jeho částech, a navrhuje hovořit místo toho jen o „funkčních systémech“ (Funktionssysteme) [Nassehi 1999: 20].

\section{SUPERVIZE, ANEBO ORGANIZOVANÁ NEZODPOVĚDNOST}

Do diskusí, které se po Luhmannově smrti rozvinuly kolem systémového přístupu $\mathrm{k}$ problematice řádu a integrace, zasahuje řada autorủ. Jedním $\mathrm{z}$ nich je systémový teoretik Helmut Willke [1997], který se pokouši výrazným způsobem modifikovat představy o roli politického systému.

Soudobá společnost je pro Helmuta Willka především „společností věděni“ [Pongs 2000: 243-262] a procesů globalizace. V souladu se závěry Luhmannovy analýzy Willke konstatuje, že běžnou formu jednoty tato společnost ztratila a stala se společností „polycentrickou“, a proto nevyžaduje integraci, nýbrž „supervizi“. Vyhlídky na možnosti takové supervize jsou dány šancemi, které přináší „společnost věděni“; jde nyní o to tyto šance objevovat a rozvijet je. Své vlastní pojetí supervize vytváŕi Willke $\mathrm{v}$ kritické konfrontaci s tím, jak je tento pojem chápán a užíván v současnosti. Konstatuje, že supervizi nelze zužovat na kontrolu, revizi, dohled či poradenství, i když všechny tyto prvky jsou v ní obsaženy. Pojem supervize má být vymezen „netriviálně“, jako označení pro sebereferenční, sebeřídící proces.

Supervize se, jak říká Willke, vztahuje na procesy řízení a ve své podstatě spočívá $\mathrm{v}$ jejich reflexi prostřednictvím supervizora. Není to však jen prosté opakování nebo zesílení těchto řídících procesủ a není to ani pouhý reflexivní náhled na ně. Wilke spojuje supervizi s tím, co označuje jako řizení kontextu; soudí, že supervize předpokládá supervizora, který disponuje „dodatečnými perspektivami druhého řádu“ [Willke 1997: 42]. Supervizor musí být schopen zaujmout pozici pozorovatele druhého stupně (pozorovatele pozorovatele), $\mathrm{z}$ níž lze vidět, podle jakých kritérii pozorované systémy pozorují samy sebe, a zároveň musí umět zviditelnit i to, co systémy v dủsledku toho, jakým způsobem selektují své informace, vidět ne snad že nechtějí, nýbrž nemohou. Předpokladem supervize je tedy nový přístup ke zpracování informací. 
Wilke se domnívá, že supervize jako určitý režim řízení odpovídá současné historické epoše vytváření společnosti vědění. Supervize není nějakou náhražkou kontroly ani dohledem, nýbrž samostatnou formou kooperativního a kongeniálního hledání řešení problémů [Willke 1997: 70]. Úlohu supervize přisuzuje autor politice a roli supervizora státu jako politickému systému. Nejde však o nic automatického a samozřejmého, stát by se měl do role supervizora postupně vyvinout a politika se musí naučit, jak v soudobé polycentrické a decentralizované společnosti operovat. Supervize státu nemúže být, jak říká Willke, vủči svému okolí ničím „násilným“, nýbrž musí vnitřní struktury okolních systémů respektovat.

Reflexe problémů, na které upozorn̆uje analýza funkcionální diferenciace soudobé společnosti, se stává inspirací sociologického myšlení i mimo rámec systémového paradigmatu. Dokladem toho je Ulrich Beck, který toto téma klade do kontextu koncepce rizikové společnosti. Jedním z problémů, na které se Beck orientuje, je to, co označuje výrazem ,organizovaná nezodpovědnost“ (organisierte Unverantwortlichkeit [Beck 1988: 96-112]). Kořeny tohoto jevu spočívají právě v rozdiferencování společenského systému na relativně autonomní dílčí společenské systémy s vlastní uzavřenou komunikací. Fatální je podle Becka především to, že tři klíčové dílčí systémy věda, hospodářství a politika - jsou takto vzájemně komunikačně odděleny a nedokážou navzájem efektivně kooperovat. Aktéri, kteří myslí, rozhodují a jednají pouze $\mathrm{v}$ intencích jednoho určitého systému, nejsou schopni a ani nemohou a nechtěji přijmout zodpovědnost za dủsledky svých jednání a rozhodnutí mimo tento „svủj“ dílčí systém.

A tak dělba práce, která byla považována za rozhodující evoluční přednost, odkrývá svou odvrácenou tvář a stává se v podmínkách rizikové společnosti nevýhodou, jež vyvolává otázku po smysluplnosti tohoto typu funkcionální diferenciace. Pokud jednotlivé dílčí systémy respektují pouze svoji vnitřní logiku, pak je za rizika zodpovědný „každý a zároveň nikdo“. Přes racionalitu a organizovanost, která je těmto jednotlivým systémům vlastní, se navzdory veškerému úsili dospívá $k$ tomu, že narůstá pocit nejistoty a nekontrolovatelnosti.

Rizika modernizace nelze přiřadit ani pouze $\mathrm{k}$ vědě, ani $\mathrm{k}$ ekonomice či politice; patři ke všem těmto dílčím systémům zároveň, jsou „koprodukci““ jejich nedostatečné komunikace a koordinace. Beck soudí, že systémová krize a její řešení vyžadují, aby dílčí sociální systémy dokázaly zároveň fungovat jako autonomní i jako koordinované subsystémy. Jde o to umět vidět a řešit problémy $\mathrm{z}$ perspektivy přesahující jednotlivé dílčí systémy a tím překonat stav organizované nezodpovědnosti. Aby toho bylo možné docílit, je zapotřebí nové orientace, kterou Beck charakterizuje jako „specializaci na souvislosti“ [Beck 2004: 295-297]. Této nové orientace lze dosáhnout pouze překonáním zúženého sebepojetí vědy, ekonomiky a politiky.

Problém kooperace a komunikace se však netýká pouze vztahủ mezi dílčími společenskými systémy; na něco obdobného narážíme i uvnitř samého, vnitřně velice členitého systému vědy. Bádání v oblasti rizik bývá často spojeno s konkurenčními střety mezi jednotlivými vědeckými profesemi. Vzniká tak napětí, které brání kooperaci, ačkoli situace naopak interdisciplinární spolupráci vyžaduje. Vědy proto podle Becka musí pojmout otázku rizik jako výzvu ke společné práci na jejím řešení. Jednou z kva- 
lit, které je v jejich rámci nutné pěstovat, je schopnost sebekritiky, umění priznat omyl. Především však jde o to, aby „roztřǐštěné“ vědní disciplíny dokázaly používat své poznatky interdisciplinárně a aby byly schopny je vidět v perspektivě přesahující optiku jednotlivých dílčích specializací.

Druhý problém, kterého si Beck všímá, je diferenciace vědy, tedy její „hyperkomplexita“. S postupným rozdiferencováváním jednotlivých vědních disciplín roste nepřehledné množství specializovaných poznatkủ, které mnohdy věda není schopna navzájem pospojovat a pochopit rizika jako polykauzální, multifaktorový fenomén. Zvláště pro rizika modernizace totiž platí, že je nelze převést zpět na jednotlivé izolovatelné př́činy: Rizika vykazuji přesahující vztah a sítem nadměrné specializace propadávají, jsou tím, co leži mezi specializacemi.

Navíc spolu s touto vnitřní diferenciací vědy vzniká jakýsi pluralismus nabídek $\mathrm{v}$ interpretaci zkoumaných problémů, díky kterému lze pak ke každému stanovisku nebo posudku formulovat stanovisko nebo posudek protikladný. $\mathrm{V}$ důsledku toho jsou uživatelé vědeckých informací nakonec odkázáni sami na sebe; musí se sami rozhodnout, které variantě vědeckých ,pravd“ budou věřit, a které ne. Systém vědy zatím není podle Becka schopen na rizika modernizace adekvátně reagovat. Má-li se změnit, musí se především naučit vidět a chápat souvislosti - musí se „specializovat na souvislosti“.

\section{STACI EVOLUCE?}

Představy o supervizi [Willke 1997] a o specializaci na souvislosti [Beck 2004] naznačují určité východisko z problémů, do kterých se současná funkcionálně diferencovaná společnost dostala. Pro ortodoxní následovníky Luhmannova myšlenkového odkazu však nejsou takové představy teoreticky přijatelné, což mj. dokládají i názory Georga Kneera a Armina Nassehi. Možnost pozorovat něco jako jednotu společnosti je podle těchto autorů vyloučena, nebot pro takovéto pozorování v současné funkcionálně diferencované společnosti chybí pozorovatelské stanoviště. V této společnosti neexistuje žádná ústřední instance $s$ celospolečenským dosahem, která by dokázala všechny diference systému a prostředí transcendovat a propojit je prostřednictvím smyslu. Moderní společnost už nenabízí žádné privilegované místo pro jednotící pohled na svět. Pozorování různých pozorovatelů jsou jen pozorováními mezi mnoha jinými pozorováními. Neexistuje dílčí systém, struktura a symbolika, které by ve svém vztahu $k$ okolí odkazovaly na celek. A chybí ke všemu i vysvětlení pro svět v celku [Kneer 1993: 142].

Nassehi hovoří o krizi funkcionálně diferencované světové společnosti, která představuje významné riziko a nebezpečí. Soudí, že rizikový potenciál funkcionální diferenciace spočívá právě v jejím úspěchu. S prosazováním funkcionální diferenciace „se stává stále nemyslitelnější představit si společenské místo, ze kterého nebo ke kterému by se mohly koordinovat funkcionální dílčí systémy společnosti““ [Pongs 2000: 173]. Proto se dezintegrace stává normálním případem moderního zespolečenštění.

Integrace jako „funkcionální provázanost diferencovaných části““ by, jak soudí Nassehi [1999: 16], vyžadovala něco, co z hlediska systémověteoretické perspektivy není možné: vyžadovala by lokalizovat zdroje této propojenosti někam mimo tyto jednotlivé 
funkční (dílčí) systémy, a to do jakési „celosti“ celku samého. Tak jako dnes nelze takový zdroj lokalizovat, nelze ani společnost chápat jako nějakou ontickou jednotu. Společnost je zkrátka souhrnné označení pro všechno, co operuje prostřednictvím komunikace [tamtéž]. $\mathrm{V}$ důsledku své diferenciační formy však nedisponuje žádným společným a sjednocujícím diferenciačním schématem.

Systémová diferenciace tedy, obecně vzato, préedstavuje úspěšně se prosazující strategii moderny, jež přinesla četné komunikační vymoženosti, má však i své problematické důsledky. Patří k nim nejen značně omezené možnosti kontroly jednotlivých (ve své existenci na sobě závislých) funkčních systémủ mezi sebou navzájem či otázka vztahu těchto systémủ $\mathrm{k}$ životnímu prostředí, ale především a právě diskutovaná absence integračních mechanismủ. Tomu, aby společnost mohla na tyto problémy zareagovat ,jako společnost“", brání principy funkcionální diferenciace; společnost reagovat mưže, ale vždy jen dílčím, systémově specifickým způsobem.

I když mezi sociálními vědci stále prěživá názor, že zvládnout problémy tohoto typu je především problémem politického řízení společnosti, Luhmann takové stanovisko odmítá. $\mathrm{Z}$ jeho pohledu se politické rízení společnosti ve smyslu cílené intervence do ostatních společenských subsystémů jeví jako něco nemožného. Podobně jako ostatní společenské subsystémy je i politika sebereferenčně uzavřeným komunikačním okruhem a to, co je deklarováno jako politické rízení společnosti, není ničím jiným než odpovídajícím způsobem profilované sebemonitorování politiky. Chápe-li politika sebe sama jako instanci řídící jiné společenské systémy, pak se vlastně dopouští sebeklamu, který sama nejen vytvořila, ale také mu i podléhá, přestože musí často registrovat, jak její snahy ztroskotávají. Operace politického systému mají nesporně i řadu prokazatelných účinkủ. Protože však jde o operace odehrávající se na principu rezonance a strukturálních vazeb probíhajících přes „systémové rozhrani“", dochází vždy $\mathrm{k}$ určitému komunikačnímu posunu a zkreslení. Snažíli se tedy nap̌r. politika ovlivnit vědu, stane se, že pro vědecký systém představuje taková intervence cosi klamného, co nevychází $\mathrm{z}$ jeho imanentního kódu vědecké pravdy a nepravdy; zatímco politika přínáší zdeformovaný efekt $v$ té podobě, že její záměr musí být upraven tak, aby se hodil do komunikačních souvislostí vědy (a tím se vzdaluje pủvodní intenci).

Ostatně i kdyby se ze systémové perspektivy jevilo politické ŕízení celkového společenského systému jako reálné, přesto by je bylo možné označit za nepotřebné a patrně i škodlivé, nebot Luhmann [1984: 645] v jednom ze svých typických lapidárních tvrzení konstatuje, že „pro přežití stačí evoluce“. Přežití, které má na mysli, znamená trvalou reprodukční schopnost moderní společnosti i s její hyperkomplexitou, která je dána velkým počtem paralelně existujících subsystémủ a jejich nejrozmanitějších vzájemných strukturálních vazeb. Každé „chytrácké“ úsilí, které se snaží do této nepréhledné komplexity zasahovat, je podle Luhmanna nutně velmi problematické (protože obvykle není dostatečně komplexní) a musí počítat s nezdarem. Dokladem toho jsou podle Luhmanna [1981] problémy, se kterými se potýká moderní sociální stát, který přičítá své politice odpovědnost za celou společnost, a v dủsledku této ambice, tedy zejména pro nadměrné sebepřetěžování politického systému, pak v tomto úsilí pravidelně ztroskotává. Luhmann naproti tomu doporučuje odstoupit od expanzivního chápání politiky, jež by měla učinit restriktivní obrat směrem k regulaci vzniklých spole- 
čenských konfliktů kolektivně závaznými rozhodnutími, aniž by si tím nárokovala pozici společensky řídícího subsystému.

Takto vedená argumentace ve svých dủsledcích logicky směruje $\mathrm{k}$ otázce, zda máme skutečně uvěrit tomu, že funkcionálně diferencovaná společnost - jako de facto jediná myslitelná forma (bez alternativy) soudobé společnosti - je sama schopna pustit se do svých vlastních problémů a řešit je. Luhmann sám však takovou otázku explicitně neformuluje, natož aby na ni hledal systematickou odpověd. Budoucnost zůstává v jeho pojetí principiálně otevřená nejrůznějším možnostem a neexistují žádné zákonitosti, které by evoluční vývoj směrovaly $\mathrm{k}$ určitému cili. Jedna $\mathrm{z}$ teoretických možností, o které lze $\mathrm{v}$ intencích systémové teorie uvažovat, je např. „vydiferencováni“" nových (sekundárních) společenských subsystémů, jejichž posláním by bylo zabývat se odstraňováním negativích následk funkcioná jejichž posice. Něktě̌i z Luhmannových komentan [Schimank 2000: 141] soudí, že ve vztahu společenského systému $\mathrm{k}$ jeho přirodnímu prostředí by zárodkem takového budoucího systému mohly být existující ekologické organizace, zatímco kód by byl orientován ve smyslu dichotomie udržitelného a neudržitelného. To je ovšem zatím pouze jakási hypotéza, která ještě nevypovídá nic o tom, jakou by mohl mít takový postup reálnou šanci na prosazení a na úspěšnost.

\section{Literatura}

BARALDI, C. - CORSI, G. - ESPOSITO, E. 1997. GLU: Glossar zur Niklas Luhmanns Theorie sozialer Systeme. Frankfurt am Main: Suhrkamp.

BAUMAN, Z. 1995. Úvahy o postmoderni době. Praha: SLON.

BECK, U. 1988. Gegengiffe: Die organisierte Unverantwortlichkeit. Frankfurt am Main: Suhrkamp.

2004. Riziková společnost: Na cesté k jiné moderné. Praha: SLON.

. Wilhelm Fink Verlag
UHMANN, N. 1981.

- 1984. Soziale Systeme: Grundriß einer allgemeinen Theorie. Frankfurt am Main: Suhrkamp.

1986. Okologische Kommunikation: Kann
einstellen? Opladen: Westdeutscher Verlag.

- 1988. Die Wirtschaft der Gesellschaft. Frankfurt am Main: Suhrkamp.

- 1994. Protest. Systemiheorie und soziale Bewegungen. Frankfurt am Main: Suhrkant.

- 1995. Soziologische Aufklarung 6. Die Soziologie und der Mensch. Opladen: Westdeutscher Verlas.

- 1997 Die Gesellschaft der Gesellschaft. Frankfurt am Main:Suhkamp.

LYOTARD, J. F. 1993. O posm

NASSEHI, A. 1999. Differenzierungsfolgen: Beiträge zur Soziologie der Moderne. Opladen: Westdeutscher

PONGS, A. 2000a. V jaké společnosti vlastně žijeme? Společenské koncepce - srovnáni. Svazek 1. Praha: ISV nakladatelství.

SCHIMANK, U. 2000. „Ökologische Gefahrdungen, Anspruchsinflationen und Exklusionsverkettungen Niklas Luhmanns Beobachtung der Folgeprobleme funktionaler Differenzierung." In: Schimank, U. Volkmann, U. (eds.). Soziologische Gegenwartsdiagnosen I. Opladen. Leske + Budrich.

SRUBAR, I. 2002. Doslov: ,KK architekture Luhmannovy teorie autopoietickych systémư“. In: Luhmann, N. Laska joto vasen. Paradigm lost. Praha: Prostor, s. 263-278.

WTLLKE, H. 1997. Supervision des States. Frankfurt am Main: Subrkamp.

\section{Systems Differentiation - the Risk Potential of Contemporary Society}

Summary

This paper is based on the ideas of systems theory as formulated by Niklas Luhmann. Unlike his predecessor Talcott Parsons, Luhmann foregrounds the question not of systems integration, but differentiation. For Luhmann modern society is a functionally differentiated society, i.e. it is composed of heterogeneous but equal parts which are relatively independent and are defined as social subsystems. Luhmann's analysis presents contemporary society as a whole differentiated into functionally dependent yet autonomous sub-existence of potential unitying forces or infogration of the exis coblem is the non-existence of means of "metacommunication". The development of specialised media and codes in the individual sub-systems increases the overall complexity of the social system, but does not entail the metacommunication that would make possible the self-observation and self-reference of the social system as a whole. 